(Уманський державний педагогічний університет імені Павла Тичини) lydachernichenko@meta.ua ORCID: $0000-0001-8455-8869$

\title{
МЕТОДОЛОГІЧНІ ЗАСАДИ ПІДГОТОВКИ МАЙБУТНІХ ЛОГОПЕДІВ ДО ІННОВАЦІЙНОӤ ДІЯЛЬНОСТІ В УМОВАХ ІНКЛЮЗИВНОЇ ДОШКІЛЬНОЇ ОСВІТИ
}

У статті розглядається та теоретично обтрунтовується основні методологічні підходи підготовки логопедів до інновачійної діяльності в умовах інклюзивної дошкільної освіти. Розкрито зміст системного, компетентнісного, особистісно-орієнтованого та діяльнісного підходів. Також схарактеризовано сукупність принщипів організацї та окреслено шляхи вдосконалення системи підготовки майбутніх логопедів до інновачійної діяльності в умовах інклюзивної дошкільної освіти.

Ключові слова: методологічний підхід, системний, компетентнісний, діяльнісний, особистісноорієнтовний, інноваційна діяльність, інклюзивна освіта.

Постановка проблеми дослідження. Сьогодні в Україні відбувається перегляд пріоритетів у системі професійної підготовки логопедів. Насамперед процеси реформування системи освіти, які відбуваються зараз не тільки в Україні, але й в країнах Європи, приводять до необхідності переосмислення ролі майбутнього логопеда в новому столітті.

Сучасному інклюзивному садку потрібен фахівець (логопед), який творчо реалізує нові технології навчання, постійно досягає високих результатів у своїй професійній діяльності, для якого характерною $є$ готовність до неперервного самовдосконалення. В освіті відбуваються соціально-педагогічні зміни, пов'язані з уведенням нових державних освітніх стандартів, переходом на новий зміст і структуру освіти. Постає питання про сучасні методологічні підходи професійної підготовки логопеда, необхідність методологічного обгрунтування визначеної педагогічної проблеми.

Аналіз останніх досліджень і публікацій. Проблема удосконалення процесу підготовки майбутніх логопедів до роботи в умовах інклюзивної освіти до тепер не була предметом спеціального наукового дослідження, хоча у плані вдосконалення професійної підготовки майбутніх фахівців корекційної освіти деякі її аспекти вивчалися побіжно: підвищення якості підготовки майбутніх вчителів-дефектологів до реалізації різних функцій професійної діяльності (В. Бондар, С. Миронова, Н. Пахомова, К. Островська, В. Тищенко, І. Демченко, Д. Шульженко, А. Шевцов, М. Шеремет тощо). Проте, незважаючи на значущість отриманих науковцями результатів, дотепер остаточно не визначена як концептуальна, так i організаційно-педагогічна основа підготовки майбутнього вчителя-логопеда до роботи в умовах інклюзивного навчання.

У цій статті маємо на меті акцентувати увагу на кількох методологічних підходах, які сьогодні визначають інституційний прогрес у сфері з підготовки конкурентоспроможних фахівців на ринку освітніх послуг для дітей з тяжкими порушеннями мовлення.

Виклад основного матеріалу. Нормативна сторона методології пов'язана 3 вивченням загальних принципів підходу до дослідження педагогічних об'єктів, з дослідженням системи загальних і приватних методів і прийомів. Методологічний рівень педагогічного дослідження грунтується на провідній засаді, що на базі емпіричних і теоретичних досліджень формулюються загальні принципи і методи дослідження педагогічних явищ.

Філософський словник визначає методологію як систему принципів і способів організації й побудови теоретичної й практичної діяльності, а також учення про цю систему [1]. В узагальненому вигляді методологія розглядається як учення про організацію діяльності, що визначає й предмет методології організацію діяльності.

Реалізація методологічних підстав наукового аналізу явищ і процесів здійснюється за допомогою застосування методологічних підходів.

У загальноприйнятому розумінні поняття підхід означає сукупність прийомів, способів, використовуваних для впливу на кого-небудь, вивчення чого-небудь, ведення справ. У сучасній філософії поняття методологічного підходу розглядається по-різному різними вченими. Так, Н. Стефанов визначає методологічний підхід як "сукупність (систему) принципів, які визначають загальну мету і стратегію відповідної діяльності" [2].

Є. Юдін і І. Блауберг розглядають методологічний підхід, як "принципову методологічну орієнтацію дослідження, як точку зору, з якої розглядається об'єкт вивчення (спосіб визначення об'єкта), як поняття або принцип, який керує загальною стратегією дослідження" [3].

Згідно з рекомендаціями Болонського процесу i розробкою Державного галузевого стандарту "Спеціальна освіта" професійна підготовка логопедів базується на: 
1) системному підході, з позицій якого здійснюється професійна підготовка майбутніх логопедів як складна, соціальна, динамічна, самоорганізована система, у межах якої системоутворювальні елементи вступають у специфічні навчально-професійні відносини (В. Афанасьєв, В. Загвязинський, І. Зязюн);

2) компетентнісному підході, що визначається новою концепцією освіти, відповідно до неї складником державних освітніх стандартів $є$ предметні компетенції фахівця (Н. Бібік, В. Буряк, I. Малафіїк, О. Пометун, О. Савченко, В. Якунін та ін.);

3) особистісно-орієнтованому підході, який базується на суб'єктному підході до діяльності індивіда (Б. Ананьєв, І. Бех, Л. Виготський, І. Зимня);

4) діяльнісному підході, який теоретично обгрунтували (Г. Атанов, Г. Балл, Л. Виготський, О. Леонтьєв, С. Рубінштейн, В. Семиченко), згідно з яким розвиток особистості здійснюється під час діяльності, в якій вона бере участь.

Отже, розглянемо ширше найголовніші з методологічних підходів підготовки майбутніх логопедів до інноваційної діяльності в умовах інклюзивної освіти.

Cистемний nidxid застосовується при дослідженні складних об'єктів, що становлять органічне ціле. Дослідити педагогічний об'єкт 3 позиції системного підходу означає проаналізувати внутрішні та зовнішні зв'язки та відносини об'єкта, розглянути всі його елементи з урахуванням їх місця і функцій в ньому. Основними принципами реалізації системного підходу, які уточнюють його сутність, є:

- принцип цілісності, який відображає специфіку властивостей системи, залежність кожного елемента, властивості і відносини всередині системи від їх місця і функцій всередині цілого;

- принцип структурності, що дозволяє описувати системи як структури через розкриття сукупності зв'язків і відносин між її елементами;

- принцип взаємозалежності зовнішніх і внутрішніх факторів системи;

- принцип ієрархічності, який передбачає розгляд об'єкта в трьох аспектах: як самостійної системи, як елементу системи більш високого рівня, як системи більш високого ієрархічного рівня по відношенню до іiї елементів, що розглядаються, в свою чергу, як системи;

- принцип множинності уявлення системи, що означає необхідність створення безлічі моделей для опису системного об'єкта;

- принцип історизму, що вимагає вивчення системи і їі елементів не тільки як статичних, але і як динамічних, що мають історію свого розвитку.

Особливу увагу К. Ушинський приділяв значенню системи знань у засвоєнні навчального матеріалу. Учений писав: "Тільки система, звичайно, розумна, що виходить із самої суті предметів, дає нам повну владу над нашими знаннями. Голова, наповнена уривчастими, незв'язаними знаннями подібна на комору, в якій усе без ладу і де сам господар нічого не знайде; голова, де тільки система без знань, схожа на крамницю, в якій на всіх ящиках є надписи, а в них порожньо" [4].

Відтак, системний підхід - це напрямок дослідження, вивчення світу, в основі якого лежить розгляд об'єктів як системи, орієнтація на розкриття цілісності об'єкта, виявлення різноманітності зв'язків у ньому і приведення їх до єдиної теоретичної картини. Системний підхід забезпечує розробку і реалізацію навчального процесу 3 точки зору структурування змісту навчального матеріалу та загального управління процесом його засвоєння.

Для виконання професійної діяльності майбутній логопед повинен володіти певними знаннями, вміннями, навичками, значущими особистісними якостями і бути здатним здійснювати корекційнопедагогічну, діагностично-консультативну, дослідницьку та культурно-просвітницьку діяльність в установах освіти, соціальної сфери і охорони здоров'я. Система знань, умінь, навичок і якостей формується в процесі реалізації компетентнісного підходу.

Реалізація компетентнісного підходу в професійній підготовці логопеда до інноваційної діяльності в умовах інклюзивного навчання, насамперед, передбачає розробку змісту навчальних дисциплін і практичної підготовки студентів до організації і впровадження інклюзивної форми навчання 3 урахуванням компетенцій майбутньої діяльності фахівця в галузі корекційної освіти.

Ми розглядаємо компетентнісний підхід у вищій освіті як своєрідну відповідь на виклик часу, в якому відбувається становлення фахової, творчої і соціально відповідальної індивідуальності. Виходячи 3 того, що компетентнісний підхід проголошено одним із стратегічних напрямів розвитку освіти в Україні, $\epsilon$ потреба в актуалізації ключових понять цього підходу.

В наукових джерелах по-різному визначають ключові поняття компетентнісного підходу компетенцію і компетентність, але останнім часом ці дефініції стають більш усталеними в сучасному понятійно-категоріальному апараті.

Компетентність визначається як оцінна динамічна категорія, що характеризує людину як суб'єкта діяльності, іiі здатність успішно виконувати свої повноваження у тій чи іншій професійній сфері; виражається через знання, розуміння, уміння, цінності, інші якості особистості.

Компетентнісний підхід розглядається, як одна 3 підстав оновлення сучасної освіти, оскільки дозволяє ліквідувати розрив між когнітивним, діяльнісним і особистісним рівнями розвитку майбутнього 
фахівця. Він припускає формування такого нового змісту освіти, який би охоплював цілісний індивідуальний досвід вирішення майбутніми фахівцями професійних проблем на підставі здобуття відповідних компетенцій [5].

Відтак, компетентнісний підхід до змісту підготовки майбутніх логопедів для інноваційної діяльності в умовах інклюзивного середовища висуває на перше місце не інформованість майбутнього фахівця, а його уміння вирішувати проблеми, що виникають, принаймні, у пізнанні та поясненні явищ дійсності, які відбуваються в інклюзивному середовищі; при освоєнні сучасних технологій і стратегій інклюзивного навчання; у стосунках людей, в етичних нормах, при оцінюванні власних дій в професійній діяльності, способів вирішення конфліктів тощо.

Згідно з компетентнісним підходом, саме компетентності розглядаються в якості бажаного результату професійної освіти фахівців, у тому числі й фахівців у сфері розвитку, навчання і виховання дітей 3 тяжкими порушеннями мовлення. Невипадково тому основні напрями досліджень зарубіжних і вітчизняних учених сконцентровані у площині визначення і уточнення обсягу компетенцій, необхідних для ефективної професійної діяльності у різних галузях, розробленням критеріїв їх оцінки й ефективності засобів їх формування з урахуванням спеціалізації їх професійної діяльності.

Автори колективної монографії (Н. Бібік, Л. Ващенко, О. Локшина, О. Овчарук, Л. Парашенко, О. Пометун, О. Савченко, С. Трубачева) стверджують, що компетентнісний підхід не єдиний чинник, що сприяє модернізації змісту освіти [6]. На їхню думку, він передусім доповнює низку освітніх інновацій і класичних підходів, що допомагають освітянам гармонійно поєднувати позитивний досвід для реалізації сучасних освітніх цілей.

Крім того, реалізація компетентнісного підходу до фахової підготовки майбутніх логопедів для інноваційної діяльності в умовах інклюзивного навчання вимагає дотримання чіткого алгоритму, який умовно можна представити в три етапи.

На першому, змістовому, етапі потрібно:

- оновити зміст навчальних психолого-педагогічних дисциплін, які забезпечують формування компетентностей у сфері організації і забезпечення інклюзивного навчання дітей 3 тяжкими порушеннями мовлення в загальноосвітньому просторі;

- доповнити варіативну частину освітньо-професійної програми підготовки фахівців питаннями 3 теорії і методики інклюзивного навчання, які відображають компетентнісні основи особистіснопрофесійної освіти;

- оновити зміст практичної підготовки студентів з урахуванням майбутніх компетенцій діяльності в інклюзивному середовищі;

- забезпечити самостійну роботу студентів відповідним методичним та інформаційним супроводом через розробку електронних навчальних курсів з інклюзивної освіти.

На другому, технологічному, етапі обов'язковим є: застосування активних форм і методів навчання; використання особистісно-орієнтованого підходу до кожного суб'єкту навчальної діяльності.

Оцінювальний етап передбачає розробку і впровадження засобів діагностики на компетентнісній основі.

Відомо, що набуття компетенцій відбувається поступово в процесі навчання, відповідно, й рівень компетентності студента до організації, впровадження і забезпечення інноваційної діяльності в інклюзивному навчанні на різних етапах навчання буде різним.

Отже, компетентнісний підхід у підготовці майбутніх логопедів у вищій школі дозволить сформувати базові компетенції для успішної реалізації власного потенціалу, досвіду та виконання на високому рівні професійних обов'язків.

Особистісно-орієнтований підхід реалізується через насиченість змісту освіти життєво важливим пізнавальним матеріалом, готовність педагогів до спільного навчання дітей із рівним рівнем психофізичного розвитку (зокрема, прийняття, розуміння та позитивне ставлення до них Є. Бондаревська, В. Данильчук, А. Доброянов В. Кан-Калик, В. Сєріков та ін.) тощо. Основа концепції особистісно-орієнтованого підходу базується на принципі спільності двох планів впливу: зовнішнього (процесуального) і внутрішнього (психологічного). При цьому значущими характеристиками цього підходу можна назвати рефлексію, діалог і суб'єктність.

Особистісно-орієнтований підхід:

- стверджує уявлення про сутність людини як особистості;

- орієнтує організацію педагогічного процесу, а особистість як мету, результат і критерій ефективності;

- вимагає визнання унікальності особистості, права на свободу і повагу;

- використовує опору на природний процес розвитку творчого потенціалу, саморозвитку особистості.

У педагогіці особистісно-орієнтований підхід розглядає підготовку логопеда, як абсолютну цінність, що розвивається в діаді "суб'єкт-студент- суб'єкт-викладач", побудоване на принципах співпраці та свободи вибору студентом змісту освіти з метою задоволення освітніх, духовних та життєвих потреб. В 
рамках даного підходу передбачається опора у підготовці на природний процес саморозвитку задатків і творчого потенціалу особистості, створення для цього відповідних умов [7].

Центральне місце щодо методологічного обгрунтування підготовки майбутніх логопедів до інноваційної діяльності в умовах інклюзивної освіти займає діяльнісний підхід. У сучасній педагогічній науці цей підхід поєднуються із системним й трактуються як єдиний системно-діяльнісний підхід (Б. Ананьєв, С. Бондаревська, О. Бугрій, І. Зимня, В. Лозова, Г. Щукіна, І. Якіманська та ін.). Але їх поєднання додає додаткові важелі щодо розробки певних теоретичних положень, кожен 3 них представляє завершену сукупність вимог, які можна застосовувати окремо, а за необхідності в поєднанні.

Діяльнісний підхід виступає як теоретико-методологічна стратегія нашого дослідження і дозволяє вивчити зміст підготовки майбутнього логопеда до інноваційної діяльності в умовах інклюзивної освіти, оптимізувати способи ії формування та розвитку, визначити шляхи практичного вдосконалення.

Діяльнісний підхід: стверджує уявлення про діяльність як про основу і головну умову розвитку і формування особистості; орієнтує особистість на організацію творчої праці як найбільш ефективне перетворення навколишнього світу; дозволяє визначити найбільш оптимальні умови розвитку особистості в процесі діяльності.

Спираючись на провідні методологічні підходи опис процесу організації системності підготовки логопеда потребує визначення провідних принципів, як змістового наповнення навчальної діяльності в умовах швидкозмінюваного, технократичного, інноваційного суспільства (Н. Бібік, І. Зязюн, Л. Кондрашова, В. Кремень, А. Маслоу, К. Роджерс, О. Савченко, Г. Сковорода, А. Сманцер, В. Сухомлинський, І. Якіманська та ін.).

До принцииів організаиї якості підготовки логопеда віднесені:

- $\quad$ принции гуманістичних иңінностей та реалізації прав людини (цінність кожної особистості, рівність прав та можливостей, надання підтримки незалежно від психофізичного, соціального статусу, релігійних переконань, етнічної належності, місця проживання), що означає врахування соціополітичних, соціо-культурних, психолого-педагогічних, інших факторів соціально-економічного розвитку суспільства, що впливають на структуру і зміст професійної підготовки педагога, в цілому, та становлення системи професійної підготовки майбутнього логопеда;

- $\quad$ принции демократичності професійної підготовки майбутніх логопедів полягає у створенні рівних, найбільш сприятливих для кожного студента, можливостей для засвоєння змісту навчальних дисциплін та прояву власних здібностей і власної творчої індивідуальності у близькому для себе виді діяльності, відкриття широких можливостей для його самореалізації;

- $\quad$ приничип особистісної зорієнтованості професійної підготовки майбутніх логопедів, як системи розвитку їхньої індивідуальності, згідно із яким перевага у педагогічному процесі надається розвитку особистісних якостей: здатність учитися; глобальне мислення; функціональна грамотність; культура людського спілкування; професійна універсальність та гнучкість; професійність як інтеграція загальної освіченості та грунтовних і широких спеціальних навичок і умінь; здатність застосовувати знання в конкретних ситуаціях; самостійність і критичність мислення; відповідальність, дисциплінованість, інноваційність, акуратність, прихильність до праці; підготовленість до невідомого майбутнього; вміння пристосовуватися до змін;

- $\quad$ принциип науковості зумовлює розробку теоретико-методологічних основ професійної підготовки логопедів до роботи 3 дітьми, які мають особливі освітні потреби з ризиком виникнення порушень мовлення, програмно-методичного інструментарію, аналіз і моніторинг результатів впровадження організаційної моделі освіти, оцінка ефективності інноваційних технологій, що використовуються для досягнення позитивного результату, проведення незалежної експертизи;

- $\quad$ принцип системного підходу до процесу організації та реалізації навчально-виховного процесу підготовки логопедів до інноваційної діяльності роботи в умовах інклюзивної освіти дошкільних навчальних закладів та системи освіти в цілому;

- $\quad$ принцип інтегративності видів знань (психологічних, педагогічних, медичних тощо) передбачає врахування методологічного знання про професійну підготовку майбутнього логопеда, що передбачає загальнофілософські, загальнонаукові та частково специфічні аспекти;

- $\quad$ принции урахування когнітивних стилів студентів передбачає опору на їх пізнавальний інтерес, спільний творчий пошук педагога і студентів, активізацію учасників навчального процесу й реалізацію процесу розвитку професійної індивідуальності суб'єктів;

- $\quad$ принции контекстного навчання, що уможливлює зв'язок і наступність професійної підготовки із професійно-педагогічною діяльністю, життям та педагогічною практикою;

- принцип міжвідомчої інтеграції та сочіального партнерства, що сприяє координації дій різних відомств, соціальних інститутів, служб 3 метою оптимізації процесу освітньої інтеграції осіб 3 порушеннями мовлення. 
Отже, схарактеризувавши сукупність принципів підготовки логопедів постала необхідність окреслити шляхи вдосконалення системи підготовки майбутніх логопедів до інноваційної діяльності в умовах інклюзивної дошкільної освіти.

Цілеспрямована підготовка майбутніх логопедів до інноваційної діяльності в умовах інклюзивної освіти здійснюється за допомогою розробки і впровадження спецкурсу "Підготовка логопеда до інноваційної діяльності в умовах інклюзивної освіти", використання різних форм і методів навчання як традиційних, так і інноваційних, серед них: дослідницькі методи, методи реалізації творчих завдань, метод кейсів, креативні методи навчання ("Мозковий штурм", евристики, синектики), метод проектів, ділові, рольові, інтерактивних ігор, есе на теми інклюзивної освіти та ін.; підбором практичних завдань: графічні диктанти, кластери, "Сінквейна", використанням інформаційних технологій в навчальному процесі, блоку індивідуальних завдань, творчих робіт та ін.

Креативні методи навчання застосовується нами в процесі проведення практичних занять зі студентами, вони дозволяють узагальнити теоретичні знання і знайти шляхи реалізації їх в практичній діяльності логопеда. Метод проектів використовується на логопедичних заняттях, що дозволяє зробити освітній процес більш цілісним, системним. Впровадження в освітній процес методу проектів відкриває значні можливості для підвищення якості навчання, вирішується комплекс завдань, що включають формування у студентів всіх компонентів інноваційної культури майбутнього логопеда.

Ми приділяємо особливу увагу чіткому плануванню занять, самостійної роботи студентів, ії організації, посилення зворотного зв'язку в процесі навчання, використання в кожному компоненті процесу формування творчих завдань як засобу активізації навчальної діяльності студентів і управління нею.

Висновки. Підсумовуючи викладений матеріал, зазначимо, що теоретико-методологічною підставою для дослідження процесу підготовки майбутніх логопедів до інноваційної діяльності в умовах інклюзивної освіти послужили: системний niдxid, який орієнтує на виділення в педагогічній системі і що розвивається, перш за все, інтеграційних інваріантних системоутворюючих зв'язків і відносин; на вивчення і формування того, що в системі є стійким, а що змінним, що головним, а що другорядним. Він передбачає з'ясування внеску окремих компонентів-процесів в розвиток особистості як системного цілого; компетентнісний niдxid дозволяє сформувати базові компетенції для успішної реалізації власного потенціалу, досвіду та виконання на високому рівні професійних обов'язків у підготовці майбутніх логопедів у вищій школі; особистісно-орієнтований пiдхід стверджує уявлення про соціальну, діяльнісну і творчу сутності особистості. Визнання особистості як продукту суспільно-історичного розвитку і носія культури; діяльнісний підхід виступає в якості теоретико-методологічної стратегії нашого дослідження і дозволяє вивчити зміст підготовки майбутнього логопеда до інноваційної діяльності в умовах інклюзивної освіти, оптимізувати способи їі формування та розвитку, визначити шляхи практичного вдосконалення.

Ефективність реалізації процесу підготовки майбутнього логопеда до інноваційної діяльності в умовах інклюзивної освіти досягається завдяки використанню, як основних, так і спеціальних педагогічних принципів: гуманістичних иінностей, контекстного навчання, особистісної зорієнтованості, науковості, демократичності, урахування когнітивних стилів, інтегративності видів знань, системного підходу та принции міжвідомчої інтеграції та соціального партнерства.

Існуюча традиційна система фахової підготовки майбутніх логопедів до професійної інноваційної діяльності спрямована, насамперед, на формування у них професійної компетентності у сфері розвитку та навчання дітей з різними порушеннями мовлення в умовах інклюзивної дошкільної освіти. Проте, існуючі наразі запити суспільства на підготовку фахівців у галузі спеціальної освіти для ефективної роботи в умовах дошкільних навчальних закладів 3 інклюзивною формою навчання, не реалізуються повною мірою у системі вищої педагогічної освіти. Це обумовлено тим, що в ній не достатньо розроблено цільові установки, організаційні форми, зміст і методи підготовки корекційних педагогів, здатних ефективно вирішувати проблеми, які постають в сучасних умовах модернізації освіти дітей 3 психофізичними порушеннями. Тому, перспективи подальших досліджень вбачаємо у більш детальному визначенні й описі стану підготовки майбутніх логопеді до інноваційної діяльності в умовах дошкільної освіти.

\section{СПИСОК ВИКОРИСТАНИХ ДЖЕРЕЛ ТА ЛІТЕРАТУРИ}

1. Философский словарь / [ред. И. Т. Фролов]. - [5-е изд.] - М. : Политиздат, 1987. -350 с.

2. Стефанов Н. Мультипликационный подход и эффективность / Н. Стефанов. - М. : Прогресс, 1976. -27 с.

3. Блауберг И. В. Становление и сущность системного подхода / И. В. Блауберг, Э. Г. Юдин. - М. : Наука, 1973. $-270 \mathrm{c}$

4. Ушинский К. Д. Человек как предмет воспитания: опыт педагогической антропологи / К. Д. Ушинский. М. : ФАИР-Пресс : Гранд, 2004. - 575 с. 
5. Вербицкий А. А. Компетентностный поход и теория контекстного обучения : материалы к четвёртому заседанию методол. семинара 16 ноября 2004 г. / А. А. Вербицкий. - М. : Исследовательстий центр проблем качества подготовки специалистов, 2004. - 84 с.

6. Бібік Н. М. Компетентнісний підхід у сучасній освіті : світовий досвід та українські перспективи: бібліотека 3 освітньої політики : [монографія] / Н.М.Бібік, Л.С. Ващенко, О. І. Локшина та ін. ; під заг. ред. О. В. Овчарук. - К. : К.І.С., 2004. - 112 с.

7. Вікуліна М.А. Особистісно-орієнтований підхід у педагогіці: теоретичне обгрунтування та шляхи реалізації : [учеб. пособ.] [Текст ] / М. А. Вікуліна. - Н. Новгород : Изд-во НГЛУ ім. Н. А. Добролюбова, $2004 .-296 \mathrm{c}$.

\section{REFERENCES (TRANSLATED \& TRANSLITERATED)}

1. Fylosofskyi slovar' [Philosophical Dictionary] / [red. I. T. Frolov]. - [5-e izd.] - M. : Politizdat, 1987. - $350 \mathrm{~s}$.

2. Stefanov N. Mul'typlykatsyonnyi podkhod i effektivnost' [Multiplicative Approach and Efficiency] / N. Stefanov. M. : Prohress, 1976. -27 s.

3. Blauberh I. V. Stanovlenie i sushchnost' systemnoho podkhoda [Formation and Essence of the System Approach] / I. V. Blauberh, E .H. Yudyn. - M. : Nauka, 1973. - 270 s.

4. Ushynskiy K. D. Chelovek kak predmet vospytaniia: opyt pedahohycheskoi antropolohii [Man as a Subject of Upbringing : the Experience of Pedagogical Anthropology] / K. D. Ushynskyi. - M. : FAYR-Press : Hrand, 2004. $575 \mathrm{~s}$.

5. Verbitskii A. A. Kompetentnostnyi pokhod y teoriia kontekstnoho obucheniia : materyaly k chetviortomu zasedaniiu metodol. seminara 16 noiabria 2004 h. [Competency Hike and the Theory of Context Learning] /A. A. Verbytskyi. M. : Issledovatel'skii tsentr problem kachestva podhotovky spetsialistov, 2004. $-84 \mathrm{~s}$.

6. Bibik N. M. Kompetentnisnyi pidkhid u suchasniy osviti : svitovyi dosvid ta ukrayins'ki perspektyvy : biblioteka z osvitn'oyi polityky [Competency Approach in Modern Education: World Experience and Ukrainian Prospects : Library for Educational Policy] : [monohrafiia] [in Ukrainian] / N. M. Bibik, L. S. Vashchenko, O. I. Lokshyna ta in.; pid zah. red. O. V. Ovcharuk. - K. : K.I.S., 2004. - 112 s.

7. Vikulina M. A. Osobystisno-oriyentovanyy pidkhid u pedahohitsi : teoretychne obgruntuvannia ta shlyakhy realizatsiyi : [ucheb. posob.] [Tekst ] [Personality-oriented Approach in Pedagogy: Theoretical Substantiation and Ways of Realization] / M. A. Vikulina. - N. Novhorod : Izd-vo NHLU im. N. A. Dobroliubova , 2004 . - 296 s.

\section{Черниченко Л. А. Методологические основы подготовки будуцих логопедов к инновационной деятельности в условиях инклюзивного дочкольного образования.}

В статье рассматривается и теоретически обосновывается основные методологические подходы подготовки логопедов к инновационной деятельности в условиях инклюзивного дошкольного образования. Раскрыто содержание системного, компетентностного, личностно-ориентированного и деятельностного подходов. Также охарактеризировано совокупность принцииов организации и намечены пути совершенствования системы подготовки будущих логопедов к инновационной деятельности в условиях инклюзивного дошкольного образования.

Ключевые слова: методологический подход, системный, компетентностный, деятельностный, личностно-ориентированный, инновационная деятельность, инклюзивное образование.

\section{Chernychenko L. A. Methodological Bases for Preparing Future Speech Therapist for Innovative Activity in Conditions of Inclusive Pre-School Education.}

The article considers and theoretically substantiates the main methodological approaches of training speech therapists to innovative activity in the conditions of inclusive pre-school education. The contents of the system, competence, personality-oriented and activity approaches are revealed. The set of principles of organization is

also characterized and ways of improvement of the system of preparation of future speech therapists for innovation activity in conditions of inclusive pre-school education are outlined.

Today in Ukraine there is a review of priorities in the system of vocational training of speech therapists. First of all, the processes of reforming the education system that are taking place now, not only in Ukraine but also in

European countries, lead to the need to rethink the role of the future speech therapist in the new century. The problem of improving the process of preparing future speech therapists for work in inclusive education has not yet been the subject of a special scientific study, although some of its aspects have been studied in terms of improving the training of future specialists in correctional education.

The existing traditional system of professional training of future speech therapists for professional innovation activities is directed, first of all, to the formation of their professional competence in the field of development and education of children with different speech disorders in the conditions of inclusive pre-school education.

Key words: methodological approach, systemic, competence, activity, personality-orientation, innovative activity, inclusive education. 